\title{
KEANEKARAGAMAN LEGUM LOKAL DI BUTON SELATAN
}

\author{
Yenni B ${ }^{1}$, S. Hafidhawati Andarias ${ }^{2}$, Agus Slamet ${ }^{3}$ \\ 1 Mahasiswa Prodi Pendidikan Biologi FKIP UM Buton, Baubau, Indonesia \\ 2 Prodi Pendidikan Biologi FKIP UM Buton, Baubau, Indonesia \\ E-mail korespondensi : aslametgus@gmail.com
}

\begin{abstract}
Local legum is one of the important genetic resource materials. In South Buton, there are various types of local legum, whether cultivated or growing wild. The lack of local legum information motivation more exploration to investigate plant diversity characteristics.This study to collect data on local legum germplasm in South Buton and pre-identification potential genetic for legum breeding and their use as a functional food. Collections of morphological samples (flowers, pods, and seeds) were carried out using the exploratory method. The results of the study showed that 11 samples of local legum gene plasma were collected, based on the morphological character of local legum showed variation in flower color, pod characteristic (pod shape, pod color, and pod texture), and seed characteristics (shape and color of seed) also agronomy characteristic (the number of seeds, weight of seeds, age of planting and age of harvesting). The diversity of local legums can be used as a source of genes and alternative functional food in the future.
\end{abstract}

Keywords: local legum, South Buton, diversity

\begin{abstract}
Abstrak
Legum lokal merupakan sumber daya genetik (SDG) yang penting. Di Buton Selatan ditemukan beragam jenis legum lokal baik yang dibudidayakan maupun tumbuh liar. Informasi tentang legum lokal di Buton Selatan masih minim sehingga perlu dilakukan eksplorasi dan karakterisasi. Tujuan penelitian ini adalah untuk mendata plasma nutfah legum lokal yang terdapat di Kabupaten Buton Selatan, serta pra-identifikasi potensi genetik legum potensial untuk pemuliaan legum dan pemanfaatannya sebagai pangan fungsional. Koleksi sampel morfologi (bunga, polong dan biji) dilakukan dengan menggunakan metode jelajah (eksplorasi). Hasil penelitian ini menunjukan dari 11 jenis legum lokal yang dikoleksi memiliki variasi morfologi warna bunga, karakteristik polong (bentuk, warna \& tekstur polong) dan karakteristik biji (warna \& bentuk biji) serta karakter agronomi (jumlah biji perpolong, berat biji, serta umur berbunga \& umur panen). Keanekaragaman legum lokal ini dapat dimanfaatkan sebagai sumber gen dalam merakit varietas unggul dan sebagai alternatif pangan fungsional di masa mendatang.
\end{abstract}

Kata Kunci : legum lokal, Buton Selatan, keanekaragaman 


\section{PENDAHULUAN}

Indonesia memiliki keanekaragaman plasma nutfah legum (kacang-kacangan) yang tersebar, sebanyak 36 jenis kacang lokal yang potensinya belum sepenuhnya tergali (Fachrudin, 2000; Mead \& David, 2017). Eksplorasi palsma nutfah kacang lokal telah dilakukan di beberapa wilayah. Tercatat 27 jenis kacang lokal sebagai pangan fungsional di Pulau Timor (Puspita et al., 2017). Sebanyak 16 jenis kacang-kacangan ditemukan di Jember (Prafitasari et al., 2018) dan14 jenis dibudidayakan di Pulau Larat Maluku Tenggara (Refwallu \& Sahertian, 2020).

Legum merupakan sumber protein nabati yang mengandung protein, karbohidrat, fosfor, besi, kalsium, vitamin dan senyawa bioaktif (Ahmed \& Hasan, 2014) sehingga dimanfaatkan menjadi produk pangan darurat (Ekafitri \& Isworo, 2014). Meskipun demikian, ada legum tertentu yang mengandung racun yang dapat diatasi secara tradisional oleh masyarakat (Refwallu \& Sahertian, 2020).

Eksplorasi plasma nutfah kacang lokal merupakan kegiatan untuk mencari, mengumpulkan dan meneliti jenis tanaman kacang, guna mengkonservasinya dan memanfaatkannya sebagai sumber gen dalam perakitan varietas unggul (Astuti, 2017). Identifikasi dan karakterisasi pada dasarnya bertujuan untuk mengetahui karakter yang bernilai ekonomis atau mencari ciri khas dari varietas yang bersangkutan (Slamet et al., 2020). Kegiatan karakterisasi sumber daya genetik (SDG) legum lokal perlu dilaksanakan agar dapat diketahui jenis mana yang memiliki karakter baik yang dapat dijadikan sebagai sumber gen untuk merakit varietas unggul (Setyowati \& Kurniawan, 2018).

Terbatasnya kegiatan eksplorasi, inventarisasi plasma nutfah legum menjadi dasar dilakukan penelitiain tentang keanekaragaman legum lokal di Buton Selatan. Penelitian ini bertujuan untuk melakukan pendataan plasma nutfah legum lokal yang terdapat di Kabupaten Buton Selatan, serta pra-identifikasi potensi genetik legum potensial. Informasi ini dapat digunakan untuk meningkatkan efektivitas seleksi berbagai karakter penting dalam program pemuliaan legum dan pemanfaatan legum sebagai pangan fungsional di masa mendatang.

\section{METODE PENELITIAN}

Penelitian ini tergolong deskriptif kualitatif yang dilaksanakan di Kabupaten Buton Selatan pada Bulan Februari - April 2018. Lokasi Pengambilan sampel dilakukan di 3 (tiga) pasar Kecamatan di Kabupaten Buton Selatan yaitu Pasar Lapandewa, Sampolawa, dan Batauga. Pemilihan ini didasarkan masih adanya pedagang yang menjual legum lokal. Metode Pengambilan sampel dilakukan dengan dua tahapan yaitu (1) metode jelajah ke lahan pertanian masyarakat berdasarkan informasi dari pedagang; dan (2) identifikasi. Karakter morfologi yang diidentifikasi meliputi warna bunga; bentuk, warna \& tekstur polong; serta warna \& bentuk biji. Selain itu juga diamati karakter agronomi yang meliputi jumlah biji perpolong, berat biji (per 100 biji), serta umur berbunga dan umur panen. Identifikasi lanjut mengacu pada, Tjitrosoepomo (1988), Van Steenis, (2011) dan Puspita et al., (2017) Puspita et al (2017). Teknik pengumpulan data melalui tahapan observasi, wawancara dan studi dokumentasi. Teknik analisis data mengadopsi model alir Huberman \& Miles. 


\section{HASIL DAN PEMBAHASAN}

Legum lokal merupakan salah satu tanaman yang masih dibudidayakan oleh masyarakat Lapandewa di Kabupaten Buton Selatan. Dari hasil inventarisasi ditemukan 11 jenis legum yang tergolong dalam 6 genus sebagai berikut.

Tabel 1. Jenis-jenis Legum lokal di Buton Selatan

\begin{tabular}{lll}
\hline \multicolumn{1}{c}{ Nama Lokal } & \multicolumn{1}{c}{ Nama Indonesia/ Nama Ilmiah } & Genus \\
\hline Hapa-hapa & Kac. Kratok/ Phaseolus lunatus & Phaseolus \\
Guramba & Kac. Komak/ Labla purpureus & Labla \\
Kambue & Kecipir/ Psophacarpus tetragonolobus & Psophocarpus \\
Lawue & Kac. Tunggak/ Vigna unguiculate & Vigna \\
Kuna-kuna & Kac. Uci/ Vigna umbellata & Vigna \\
Koloure bula & Kac. Gude putih/ Cajanus cajan Var. a & \\
Koloure mokito & Kac. Gude hitam/ C. cajan Var. b & \\
Koloure samara & Kac. Gude coklat/ C. cajan Var c. & Cajanus \\
Koloure samara mocuka & Kac. Gude coklat tua/ C. cajan Var. d & \\
$\begin{array}{l}\text { Koloure bula kakito } \\
\text { Koloure wuta-wuta }\end{array}$ & Kac. Gude putih bintik hitam/ C. cajan Var. e \\
mokito & Kac. Gude hitam keunguan/ C. cajan Var. f & \\
\hline
\end{tabular}

Pada penelitian ini ditemukan 6 genus legum lokal yang meliputi Hapa-hapa (kacang kratok), Guramba (kacang komak), Kambue (kacang kecipir), Lawue (kacang tunggak), Kuna-kuna (kacang uci), dan Koloure (kacang gude). Umumnya legum lokal ini dibudidaya oleh masyarakat dan beberapa diantaranya tumbuh liar.

Keragaman legum lokal yang ditemukan di Buton Selatan ini dapat dibedakan berdasarkan karakter morfologi dan agronomi. Keragaman morfologi dijumpai pada karakter bunga (warna bunga), polong (warna dan bentuk polong) dan karakter biji (warna dan bentuk biji). Karakter morfologi ini memperlihatkan perbedaan yang bervariasi dari keenam jenis legum di Buton Selatan (Tabel 2)

Tabel 2. Karakter morfologi legum lokal

\begin{tabular}{|c|c|c|c|c|c|}
\hline \multirow{2}{*}{ Jenis } & \multirow{2}{*}{$\begin{array}{l}\text { Warna } \\
\text { Bunga }\end{array}$} & \multicolumn{3}{|c|}{ Polong } & \multirow[t]{2}{*}{ Bentuk Biji } \\
\hline & & Bentuk & Tekstur & Warna & \\
\hline Kacang kratok & Putih & Lonjong pipih & Halus & Krem & Ginjal \\
\hline Kacang komak & Ungu & $\begin{array}{l}\text { Pipih } \\
\text { menggembung }\end{array}$ & Halus & Krem & Bundar telur \\
\hline Kacang kecipir & Ungu & Lonjong pita & Kisut & Coklat tua & Bulat \\
\hline Kacang tunggak & Ungu & Lonjong pipih & Halus & Krem & Bulat Panjang \\
\hline Kacang uci & Kuning & Lampai & Halus & Hitam & Lonkong \\
\hline Kacang gude & Kuning & Sabit & Halus & Hitam & Bulat \\
\hline
\end{tabular}

Variasi warna bunga legum ditentukan oleh adanya pigmen antosianin, antosantin, dan pigmen plastid yang terdapat di dalam sel. Menurut Slamet (2018) dalam penelitiannya terhadap keragaman genetik bunga kembang sepatu, pigmen antosianin menentukan warna merah, biru dan ungu, sedangkan pigmen antosantin menentukan warna kuning. Karakter fenotip (warna bunga) akan terekpsresi jika ada interaksi antara faktor gen dan faktor lingkungan. Selain warna bunga, karakter morfologi polong dan biji juga menjadi ciri 


\section{Media Agribisnis}

Vol. 4, Issue 2, November 2020

\section{P-ISSN: 2527-8479 E-ISSN: 2686-2174}

pembeda. Trustinah et al., (2017) menyatakan adanya variasi bentuk dan tekstur polong serta bentuk biji dipengaruhi oleh faktor genotip, lingkungan, dan interaksi genotip dengan lingkungan. Demikian pula dengan karakter warna polong. Warna polong tua tanaman kacang juga bervariasi di mulai coklat tua, hitam, dan krem. Menurut Sa'diyah et al., (2013) perbedaan warna polong merupakan keragaman sifat genetis yang dimiliki setiap varietas.

Keragaman morfologi selanjutnya dapat diamati dari warna biji legum (Gambar 1). Biji lgum yang berwarna merah, hitam dan coklat diduga mengandung pigmen antosianin. Menurut Sri et al., (2015) antosianin merupakan bagian dari flavonoid yang berperan sebagai pigmen dan bersifat antioksidan. Kadar antosinain menentukan intensitas warna gelap dan berkorelasi dengan aktivitas antioksidan.

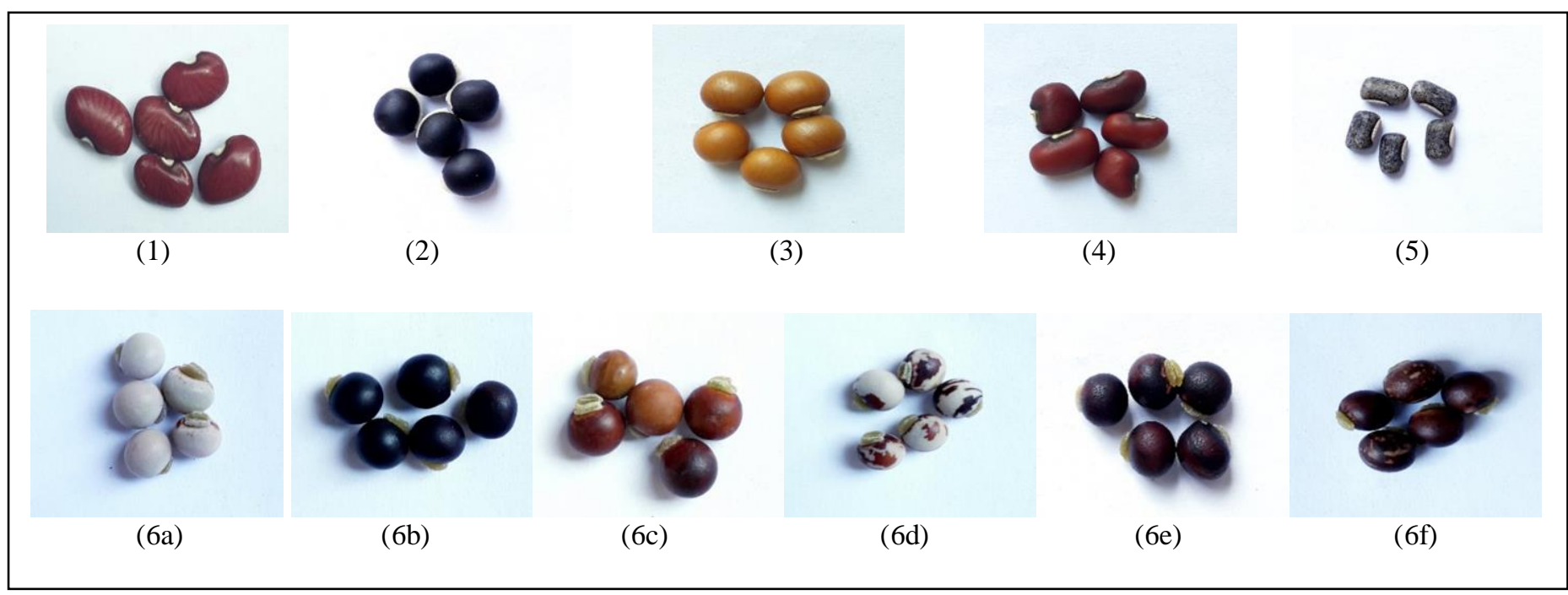

Gambar 1. Variasi warna legum lokal. (1) Kacang kratok; (2) Kacang komak; (3) Kacang Kecipir; (4) Kacang tunggak, (5) Kacang uci; (6a) Kacang gude putih, (6b) Kacang gude hitam, (6c) Kacang gude coklat, (6d) Kacang gude putih bintik hitam; (6e) Kacang gude hitam muda; (6f) Kacang gude ungu kehitaman.

Menurut Yuniastuti et al., (2020) perbedaan karakter warna biji merupakan salah satu faktor penyebab keragaman pada setiap kacang gude. Sedangkan kacang gude yang berhasil diidentifikasi memiliki variasi warna meliputi putih, hitam, coklat, putih bintik hitam, hitam muda, dan ungu kehitaman (Gambar 1). Adanya variasi warna biji kacang gude diduga merupakan hasil penyeburkan sendiri, namun ada kemungkinan penyerbukan silang dengan bantuan serangga.

Selain parameter morfologi, karakter agronomi juga merupakan faktor pembeda jenisjenis legum lokal. Karakter agronomi meliputi jumlah biji/plong, berat biji/100 biji, umur berbunga dan umur panen (HST) dapat disajikan pada Tabel 3 berikut. 


\section{P-ISSN: 2527-8479 E-ISSN: 2686-2174}

Tabel 3. Karakter agronomi legum lokal

\begin{tabular}{lcccc}
\hline Jenis Legum & Jumlah biji/plong & $\begin{array}{l}\text { Berat biji/ } \\
\mathbf{1 0 0} \text { biji }\end{array}$ & $\begin{array}{l}\text { Umur bunga } \\
(\text { HST })\end{array}$ & $\begin{array}{l}\text { Umur panen } \\
\text { (HST) }\end{array}$ \\
\hline Kratok & $3-4$ & 24,77 & 140 & 170 \\
Komak & $1-3$ & 43,76 & 100 & 140 \\
Kecipir & $6-9$ & 30,80 & 66 & 80 \\
Kac. Tunggak & $15-17$ & 12,48 & 85 & 110 \\
Kac. Uci & $5-9$ & 3,00 & 56 & 90 \\
Kac. Gude putih & & 14,60 & 110 & 150 \\
Kac Gude hitam & & 14,37 & 110 & 150 \\
Kac Gude coklat & $2-6$ & 14,62 & 110 & 150 \\
Kac Gude hitam muda & & 15,57 & 110 & 150 \\
Kac Gude putih bintik hitam & & 14,22 & 110 & 150 \\
Kac Gude ungu kehitaman & & 14,37 & 110 & 150 \\
\hline
\end{tabular}

Ket : HST (hari setelah tanam)

Berdasarkan Tabel 3, Jumlah biji perpolong yang terbentuk ditentukan oleh sifat genetik setiap jenis legum. Demikian pula hanya dengan berat biji, ukuran biji maksimum ditentukan oleh faktor genetis dan kondisi biji selama pengisian Umur berbunga juga menunjukan adanya variasi. Umur berbunga yang lambat dapat menyebabkan pembentukan polong dan pengisian biji menjadi terlambat. Lamanya periode pembentukan polong tergantung dari sifat genetik dan lingkungan. Umur berbunga tergantung pada jenis legum (Nilahayati \& Putri, 2015). Parameter lain yang juga diamati adalah umur panen. Umur panen setiap tanaman dipengaruhi oleh faktor genetik. Nugroho et al., (2016) melaporkan umur panen tanaman kacang ditentukan berdasarkan tingkat kematangan polong dan bobot polong pertanaman yang mencapai standar konsumsi tertinggi. menyatakan cepat dan lambatnya umur panen d di pengaruhi oleh faktor umur bunga, varietas, faktor lingkungan dan faktor cuaca (Nilahayati \& Putri, 2015).

Legum merupakan bahan pangan yang sangat penting dan potensial untuk dikembangkan (Aulya, 2018). Bagian yang umumnya dapat dikonsumsi adalah polong dan biji. Legum lokal asal buton selatan hanya sebatas dijadikan sebagai campuran tepung ubi kayu (kasuami/kasangkola), campuran jagung (kambose/kapusu) dan sayur. Indria et al., (2015) menyatakan tanaman kecipir digunakan sebagai sayur. Legum lokal sangat berpotensi untuk dikembangkan dan bernilai ekonomis. Kacang tunggak dimanfaatkan sebagai bahan pembuatan protein nabati berkalsium tinggi (Fitriana, 2015). Kacang uci dapat diolah menjadi tepung brownies (Puspita et al., 2017) dan beberapa jenis legum lainnya dapat dijadikan alternatif bahan baku pembuatan tempe seperti kacang gude, kacang komak dan kacang kratok (Jayanti, 2019).

\section{KESIMPULAN}

Sebanyak 11 jenis legum lokal yang berhasil diinventarisasi dan memperlihatkan variasi pada karakter morfologi (warna bunga, warna $\&$ bentuk polong, warna $\&$ bentuk biji) dan karakter agronomi (jumlah biji perpolong, berat biji, umur berbunga, \& umur panen). Variasi legum lokal asal Buton Selatan ini dapat dievaluasi \& dikarakterisasi menjadi sumber 


\section{P-ISSN: 2527-8479 E-ISSN: 2686-2174}

daya genetik (SDG) untuk perakitan varietas unggul serta dapat diolah menjadi pangan fungsional di masa mendatang.

\section{DAFTAR PUSTAKA}

Ahmed, S., \& Hasan, M. M. (2014). ISSN 2311-4673 Journl of Pharmacy and Pharmaceutical Sciences Legumes : An Overview. 2(1), 34-38.

Astuti, S. (2017). Eksplorasi Plasma Nutfah Tanaman Pangan di Provinsi Kalimantan Barat. Buletin Plasma Nutfah. https://doi.org/10.21082/blpn.v10n1.2004.p23-27

Aulya Nanda Prafitasari, D. D. P. S. K. (2018). KEANEKARAGAMAN KACANGKACANGAN DI KABUPATEN JEMBER. Bioma : Jurnal Biologi Dan Pembelajaran Biologi. https://doi.org/10.32528/bioma.v3i2.1610

Ekafitri, R., \& Isworo, R. (2014). Pemanfaatan Kacang-Kacangan sebagai Bahan Baku Sumber Protein Untuk Pangan Darurat. Pangan, 23(2), 134-145.

Fitriana, Z. W. (2015). Pemanfaatan Kacang Tunggak ( Vigna unguiculata L.Walp ) Sebagai Bahan Pembuatan Keju Nabati Berkalsium Tinggi. SKRIPSI Universitas Islam Negeri Walisongo, Semarang.

Indria, E. D., Nasution, E., \& Siagian, L. (2015). DAYA TERIMA BROWNIES TEPUNG BIJI KECIPIR DAN KANDUNGAN GIZINYA. Jurnal Gizi, Kesehatan Reproduksi Dan Epidemiologi.

Jayanti, E. T. (2019). Kandungan protein biji dan tempe berbahan dasar kacang-kacangan lokal (Fabaceae) non kedelai. Bioscientist: Jurnal Ilmiah Biologi, 7(1), 79. http://ojs.ikipmataram.ac.id/index.php/bioscientist/article/view/2454

Nasi, K., Bahan, S., Puspita, D., Sinaga, J. P. N., Tanadi, E., Pangan, T., Kedokteran, F., Universitas, K., Satya, K., Kartini, J., \& Tengah, J. (2017). KACANG NASI ( Vigna umbellata) SEBAGAI BAHAN BROWNIES UNTUK DIVERSIFIKASI PANGAN LOKAL DI NTT. November, 710-716.

Nilahayati, \& Putri, L. A. P. (2015). Evaluasi Keragaman Karakter Fenotipe Beberapa Varietas Kedelai (Glycine max L.) di Daerah Aceh Utara. J. Floratek, 10, 36-45.

Nugroho, S. A., Purnamawati, H., \& Wahyu, Y. (2016). Penetapan Umur Panen Kacang Tanah (Arachis hypogaea L.) Berdasarkan Metode Akumulasi Satuan Panas dan Kematangan Polong. Buletin Agrohorti. https://doi.org/10.29244/agrob.v4i1.14995

Puspita, D., Palimbong, S., Pratamaningtyas, N. L., \& Nugroho, K. P. A. (2017). Analisis Proksimat Berbagai Jenis Kacang-kacangan yang Tumbuh di Pulau Timor-NTT. Seminar Nasional Teknik Kimia Kejuangan.

Refwallu, M. L., \& Sahertian, D. E. (2020). Kepulauan Tanimbar . Berdasarkan posisi geografisnya kabupaten Tanimbar memiliki batas- batas : Utara-Laut Banda; SelatanLaut Timor dan Samudera Pasifik; Barat- Gugus Pulau Babar Waktu dan Tempat Kelaan , Lamdesar Barat, dan Lamdesar Timur ). Identi. 1(2), 66-73. 


\section{P-ISSN: 2527-8479 E-ISSN: 2686-2174}

Sa'diyah, N., Widiastuti, M., \& Ardian. (2013). Keragaan, Keragaman, dan Heritabilitas Karakter Agronomi Kacang Panjang (Vigna Unguiculata) Generasi F1 Hasil Persilangan Tiga Genotipe. Jurnal Agrotek Tropika.

Setyowati, M., \& Kurniawan, H. (2018). Keragaman Karakter Morfo-Agronomis Sumber Daya Genetik Kacang Tunggak (Vigna unguiculata [L.] Walp.) Koleksi Bank Gen BB Biogen. Buletin Plasma Nutfah. https://doi.org/10.21082/blpn.v22n1.2016.p41-48

Slamet, A. (2018). The diversity of Hibiscus rosa-sinensis Based on Morphological Approach. Scientiae Educatia. https://doi.org/10.24235/sc.educatia.v7i1.2503

Slamet, A., Hisra, H., \& Rajab, R. (2020). The Characteristics of the Morphological Genotypes of Local Sorghum [Sorghum bicolor (L.) Moench] from Buton Selatan. Scientiae Educatia. https://doi.org/10.24235/sc.educatia.v9i1.6120

Sri Widyawati, P., Maya Suteja, A., Putut Suseno, T. I., Monica, P., Saputrajaya, W., \& Liguori, C. (2015). PENGARUH PERBEDAAN WARNA PIGMEN BERAS ORGANIK TERHADAP AKTIVITAS ANTIOKSIDAN. Jurnal Agritech. https://doi.org/10.22146/agritech.9434

Steenis, C. G. G. J. van, \& Steenis-Kruseman, M. J. van. (2011). Flora Malesiana. general editor, C.G.G.J. van Steenis. In Flora Malesiana. general editor, C.G.G.J. van Steenis. https://doi.org/10.5962/bhl.title.40744

Tjitrosoepomo, G., \& Tjitrosoepomo, G. (1988). Morfologi tumbuhan / Gembong Tjitrosoepomo. BOTANI - ANATOMI,Morfologi Tumbuhan / Gembong Tjitrosoepomo.

Trustinah, Kasno, A., \& Mejaya, M. (2017). Keragaman Sumber Daya Genetik Kacang Tunggak Variability of Cowpea Germplasm. Jurnal Penelitian Pertanian Tanaman Pangan.

Yuniastuti, E., Sukaya, S., Fauziyah, R. S., \& Delfianti, M. N. I. (2020). Keragaman Kacang Gude Putih (Cajanus cajan [L.] Millsp.) di Kabupaten Wonogiri, Jawa Tengah. Buletin Plasma Nutfah, 26(1), 51. https://doi.org/10.21082/blpn.v26n1.2020.p51-62 